DOI: https://doi.org/10.31933/dijms.v2i2 Received: 6 August 2020, Revised: 15 October 2020, Publish: 25 November 2020

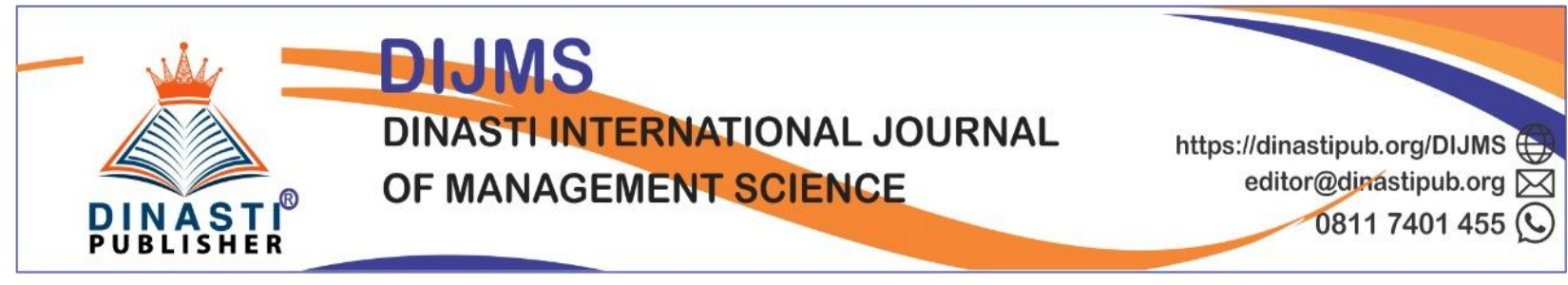

\title{
THE MEDIATING IMPACT OF ORGANIZATIONAL COMMITMENT ON THE INFLUENCE OF LEADERSHIP BEHAVIOR AND WORK ENVIRONMENT ON ORGANIZATIONAL CITIZENSHIP BEHAVIOR
} AT AJB BUMIPUTERA 1912 HEADQUARTER

\author{
Sova Arviyah ${ }^{1}$, Singmin Johanes Lo ${ }^{2}$ \\ ${ }^{1)}$ Mercu Buana University, Jakarta, Indonesia, sova.arviyah@gmail.com \\ ${ }^{2)}$ Mercu Buana University, Jakarta, Indonesia, singmin.johanes@ mercubuana.ac.id
}

\section{Corresponding Author: Sova Arviyah}

Abstract: This research aimed to analyze the mediating role of organizational commitment on the influence of leadership behavior and work environment towards organizational citizenship behavior. The research was conducted from October 2019 to April 2020 at AJB Bumiputera 1912 Headquarter. The populations in this research were 317 employees. There were 177 employees were taken as sample using Slovin's formula with 5\% error tolerance. Then, a quota sampling method was used in administering questionnaires to respondents. Data collected were analyzed using Structural Equation Modeling with the help of SmartPLS software version 3.2.8 for Windows. The results showed that leadership behavior had a slight positive, but not significant influence on organizational citizenship behavior. However, work environment had a positive and significant influence on organizational citizenship behavior. Meanwhile, the organizational commitment had positively and significantly mediated the influences of both leadership behavior and work environment on organizational citizenship behavior.

Keywords: Leadership behavior, work environment, organizational commitment, organizational citizenship behavior.

\section{INTRODUCTION}

For this surviving of an organization, the organization should create sense of belonging to employee so they would volunteer to bring forward the organization or commonly called as organizational citizenship behavior (OCB) because when employee have no high OCB behavior to organization, it would impact to its continuity.

\section{Background of Problem}

AJB Bumiputera 1912 organization which was established 107 years ago thats not easy to run organization for long time. Based on interviews result with Human Resources Manager 
and development manager of AJB Bumiputera 1912 related to these organization condition that explained about the weakness of voluntary attitude from employee regarding the progress from AJB Bumiputera, which is unable to compete with foreign insurers. This was made worse by failures to collaborate with PT Evergreen Invesco, Tbk which had an impact to disconnecting between Bhinneka Insurance and AJB Bumiputera 1912. During this split time, there restructuring occurred which eventually became moments for employee to move to Bhinneka Insurance when they had chance and opportunity. As Amounted of 200 employees from AJB Bumiputera 1912 headquarters had finally moved to Asuransi Bhinneka during restructured period on 2017 with laid off status.

These two resource people realized about this importance of volunteer attitude or usually referred as OCB to surviving the company. Lots of employee refused when they have to work on holiday to sort of the problems or when they have to work overtime after working hours. Beside that, there were few employees who has low conscientiousness regarding working hours times which consider as an important matter moreover had expected them to exceed the jobs more than company standard. This could be seen from company's data which shows the increasing of " lost hours " on employee during last 6 years. These resource people said during these restructured period there's no shown any commitment from employees. They decided to left AJB Bumiputera 1912 though they had worked for years. Not to mention all the data before they moved, there had several data that were deleted to eliminated the traces of unknown errors which made difficult for employee who were still work at AJB Bumiputera 1912. Beside that, Lots of leaders who were elected without procedure because the previous section leaders were moved to Bhinneka Insurance which made AJB Bumiputera 1912 is weaker. That two resource people were also explained that head of department was appointed as a substitute without going through fit and proper tests such as forming of cadre, making papers, presentations and interviews. It causing these leadership behaviors still not been formed properly and get many complaints from employees. The Resource people also admitted that it was very difficult to change these work environments that has been formed for long time which accustomed to relax, a lot of conversations between employee because the workspace was open without any borders and just doing routine or less innovations.

In previous research was also found that relationship of these problems. Ananda's prior research (2017) it was also found about this matters. In Ananda's research (2017) it was found the influence from leadership behavior to organization commitment, Umamaheswari research (2016) found the influence from work environment towards organization commitment, DarteyBaah's research (2019) revealed about leadership behavior influence over OCB but in Olcer's research (2014) stated opposite that transformational leadership had none influence over OCB, it triggered the research gap that would created mediation variables. Waspodo's research (2019) stated that work environment had influence towards OCB but in Syahriani's research (2017) said the opposite that work environment had none impact to OCB, so there has research gap which could triggered of these emergence of the mediation variables. Research by Mahardika (2019) explains that organization commitment had positive and significant impact against OCB. Beside that, in Pitaloka research (2014) organization commitment was succeeded in becoming intervened variable between work environment and OCB and in Pingping's research 
(2009) organizational commitment had proven to mediated and distributed the leadership variable to OCB.

From these explanations above, it shown the possibility if leadership and work environment did not reach optimal that is why the commitment to organization becomes low and it does influence to lack of organizational citizenship behavior. Based on this background, the researchers were interested to carry out the research that related to "The Mediating Impact of Organization Commitment on the Influence of Leadership Behavior and Work Environment on Organizational Citizenship Behavior at AJB Bumiputera 1912 Headquarter".

\section{LITERATURE REVIEW}

\section{Leadership Bahaviour}

According to George R. Terry in Kartono (2011) explained that leadership is an activity of influencing people so they would like to try to achieve the group goals.

In Robbins it was explained anything related to several leadership styles such as charismatic leadership styles, transformational leadership styles, and behavior leadership styles (Robbins and Judge, 2018). In this research the concept theory of leadership behavior would be used as basis. Yukl explained that leadership behavior is a leadership style which aimed to influence the satisfaction and performance on subordinates. Yukl in Lo, et.al. (2011) has divide this leadership behavior into three dimensions which is task-oriented leadership, relationsoriented leadership, transform-oriented leadership.

\section{Work Environment}

According to Sedarmayanti (2013), work environment is the overall tools, materials and surrounding environment which faced by person at works, both methods and its procedures as individuals or as groups. Based on Manpower Minister regulation number 5 from 2018 regarding Occupational Safety and Healthy Work Environment which explained that work environment is an hygiene aspect at workplace which includes factors whose presence at work that could affect safety and health on workforce.

Sedarmayanti was explained that work environment was divided into two namely physical environment and non-physical environment.

\section{Organizational Commitment}

According to Robbins statement that organization commitment is how employee would identifies the organization, its goals and hopes to remain as member of organization (Robbins and Judge, 2018). According to Meyer et. al. in Shanker (2016), organization commitment is attitude and behavior towards the owner that could defined as relative strength, individual identification and employee involvement with particular organization. Meyer and Allen in Klein that re-quoted in Luthans (2011) was explained that there are three dimensions of organization commitment, such as affective commitment, continuance commitment, normative commitment. 


\section{Organizational Citizenship Behavior (OCB)}

According to Organ in Kidwell quoted that repeated in Luthans (2011) said that OCB is individual behavior which discretionary, not directly or explicitly recognized by formal reward system and aggregately had promotes the effective functioning of organization. According to Robbins and Judge (2018), OCB is behavior from individuals which talked positively about their organization, help others and exceed the normal expectations of their work. According to Organ in Shanker (2016) there has five dimensions of OCB such as altruism, conscientiousness, civic virtue, courtesy, sportsmanship.

The research theoretical framework model was described as in below:

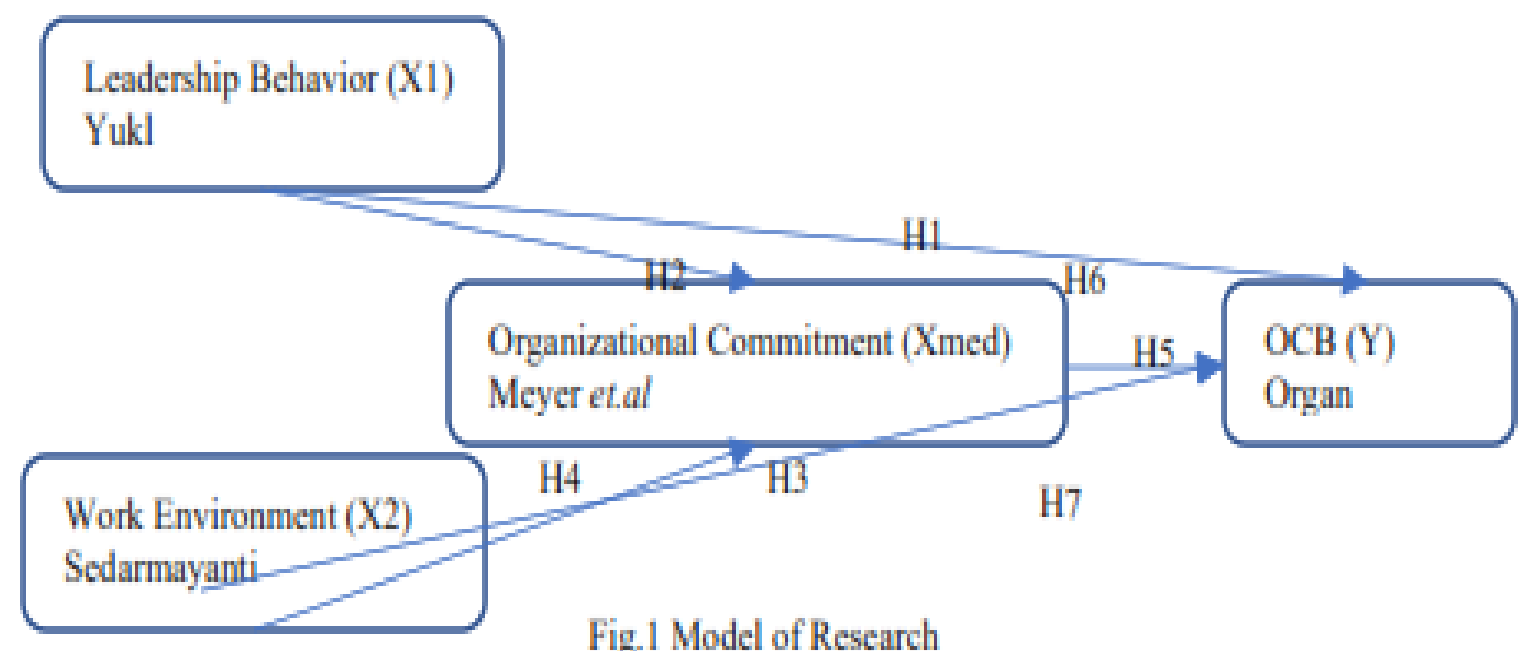

\section{Hypothesis}

H1: Leadership behavior had positive and significant influence on OCB.

$\mathrm{H} 2$ : Leadership behavior had positive and significant influence on organization commitment.

H3: Work environment had positive and significant influence towards OCB.

H4: Work environment had positive and significant towards organization commitment.

H5: Organization commitment had positive and significant impact to OCB.

H6: Leadership behavior had positive and significant influence towards OCB which mediated by organization commitment.

H7: Work environment had positive and significant influence against OCB which mediated by organizational commitment.

\section{RESEARCH METHODS}

This research used descriptive method by quantitative and causal research method. These Research objects was all employee from AJB Bumiputera 1912 headquarters as many as 177 respondents filled these questionnaires, the research sample took by Slovin formula from total population of 317 employee into 177 respondents. The sampling technique used quota sampling and data were analyzed by SmartPLS (Partial Least Square) path analysis application. 


\section{FINDINGS AND DISCUSSION}

\section{Frequency Distribution}

According to questionnaire results which distributed, $70.6 \%$ for men while $29.4 \%$ for women. In terms of age, most at ages of more than 40 years was $39.5 \%$, for ages more than 30 to 40 years as many as $27.7 \%$ and remaining $32.8 \%$ were aged 20 to 30 years. Whereas for length of work that experienced by employee, who worked for 1 to 5 years of $29.9 \%$, employee who had worked for more than 5 to 10 years were $21.5 \%$ then employee who had worked for more than 10 to 15 years were $24.9 \%$ and employee who had worked for more than 15 years which amounted 23.7\%. If based on department, there has obtained from Administration and Service as many as $2.3 \%$, Actuarial as many as $3.4 \%$, Accounting as many as $4 \%$, Legal as many as $3.4 \%$, Agency as many as $1.1 \%$, Claim as many as $9.6 \%$, Management Risk as many as $1.7 \%$, Internal Control as many as $3.4 \%$, Corporate Planning as many as $1.1 \%$, Coverage as many as $6.8 \%$, Portfolio as many as $3.4 \%$, Property as many as $2.3 \%$, Information Systems as many as $4 \%$, General as many as $10.7 \%$, Fund Management as many as $2.3 \%$, Marketing as many as $7.9 \%$, DPLK as many as $4 \%$, Subsidiaries as many as $15.3 \%$, Secretariat as many as $4.5 \%$, Foundations as many as $4 \%$.

\section{Outer Model Evaluation}

According to Ghozali and Latan (2015), the indicator considered had high level of validity if it has loading factor value greater than 0.70 . However, loading factors of 0.50 to 0.60 are still considered as acceptable Loading factor value used in this research $>0.6$ so if loading factor value $<0.6$ from estimation bookkeeping model result (outer model) then it will be removed from model and performed and recounted.

Table 1. Convergent Validity 1

\begin{tabular}{|c|c|c|c|c|c|}
\hline Variable & Indicator & Ovter Loading & Variable & Indicator & Onter Loading \\
\hline \multirow{9}{*}{$\begin{array}{l}\text { Leadeship } \\
\text { Behavior (X1) }\end{array}$} & PK1 & 0.817 & \multirow{8}{*}{$\begin{array}{l}\text { Work } \\
\text { Environment } \\
\text { (X2) }\end{array}$} & LK1 & 0.45 \\
\hline & PK2 & 0.743 & & LK2 & 0.596 \\
\hline & PK3 & 0.848 & & LK3 & 0.822 \\
\hline & PK4 & 0.648 & & LK4 & 0.655 \\
\hline & PK5 & 0.478 & & LK5 & 0.628 \\
\hline & PK6 & 0.52 & & LK6 & 0.545 \\
\hline & PK7 & 0.799 & & LK7 & 0.812 \\
\hline & PK8 & 0.863 & & LK8 & 0.811 \\
\hline & PK9 & 0.808 & \multirow{10}{*}{$\mathrm{OCB}(\mathrm{Y})$} & OCB1 & 0.706 \\
\hline \multirow{9}{*}{$\begin{array}{l}\text { Organizational } \\
\text { Commitment } \\
\text { (Xmed) }\end{array}$} & $\mathrm{KOl}$ & 0.871 & & $\mathrm{OCB} 2$ & 0.627 \\
\hline & $\mathrm{KO} 2$ & 0.842 & & $\mathrm{OCB} 3$ & 0.712 \\
\hline & $\mathrm{KO} 3$ & 0.794 & & $\mathrm{OCB} 4$ & 0.634 \\
\hline & $\mathrm{KO} 4$ & 0.857 & & $\mathrm{OCB} 5$ & 0.608 \\
\hline & $\mathrm{KO} 5$ & 0.629 & & OCB 6 & 0.75 \\
\hline & KO6 & 0.811 & & $\mathrm{OCB} 7$ & 0.602 \\
\hline & $\mathrm{KO} 7$ & 0.77 & & OCB8 & 0.813 \\
\hline & KO8 & 0.741 & & OCB9 & 0.791 \\
\hline & $\mathrm{KO9}$ & 0.599 & & OCB10 & 0.814 \\
\hline
\end{tabular}

Based on first calculation, there are some of invalid indicators that excluded from model thats why it was conduct recalculated for second times. Then convergent validity second test was performed according to outer loading result was declared valid. 
Table 2. Convergent Validity 2

\begin{tabular}{|c|c|c|c|c|c|}
\hline Variable & Indicator & Onter Loading & Variable & Indicator & Ovter Loading \\
\hline \multirow{7}{*}{$\begin{array}{l}\text { Leadeship } \\
\text { Behavior (X1) }\end{array}$} & PK1 & 0.833 & \multirow{5}{*}{$\begin{array}{l}\text { Work } \\
\text { Environment } \\
(\mathrm{X} 2)\end{array}$} & LK3 & 0.863 \\
\hline & PK2 & 0.754 & & LK4 & 0.698 \\
\hline & PK3 & 0.862 & & LK5 & 0.634 \\
\hline & PK4 & 0.622 & & LK7 & 0.838 \\
\hline & PK7 & 0.811 & & LK8 & 0.83 \\
\hline & PK8 & 0.863 & \multirow{10}{*}{ OCB $(Y)$} & $\mathrm{OCB} 1$ & 0.704 \\
\hline & PK9 & 0.811 & & $\mathrm{OCB} 2$ & 0.624 \\
\hline \multirow{8}{*}{$\begin{array}{l}\text { Organizational } \\
\text { Commitment } \\
\text { (Xmed) }\end{array}$} & $\mathrm{KO} 1$ & 0.875 & & OCB3 & 0.710 \\
\hline & $\mathrm{KO} 2$ & 0.849 & & $\mathrm{OCB} 4$ & 0.634 \\
\hline & $\mathrm{KO} 3$ & 0.803 & & $\mathrm{OCB} 5$ & 0.606 \\
\hline & $\mathrm{KO} 4$ & 0.854 & & OCB6 & 0.751 \\
\hline & $\mathrm{KO} 5$ & 0.635 & & $\mathrm{OCB} 7$ & 0.605 \\
\hline & KO6 & 0.815 & & OCB8 & 0.815 \\
\hline & $\mathrm{KO} 7$ & 0.778 & & OCB9 & 0.791 \\
\hline & $\mathrm{KO}$ & 0.724 & & OCB10 & 0.816 \\
\hline
\end{tabular}

Then discriminant validity test was performed according to cross loading result and were declared valid.

\begin{tabular}{|c|c|c|c|c|c|c|c|c|c|c|c|}
\hline Variable & Indicator & LB & WE & $\mathrm{OC}$ & $\mathrm{OCB}$ & Variable & Indicat or & LB & WE & $\mathrm{OC}$ & $\mathrm{OCB}$ \\
\hline \multirow{7}{*}{$\begin{array}{l}\text { Leadeship } \\
\text { Behavior (X1) }\end{array}$} & PK1 & 0.833 & 0.662 & 0.681 & 0.569 & \multirow{5}{*}{$\begin{array}{l}\text { Work } \\
\text { Environment } \\
(\mathrm{X} 2)\end{array}$} & LK3 & 0.694 & 0.863 & 0.679 & 0.585 \\
\hline & PK2 & 0.754 & 0.613 & 0.586 & 0.459 & & LK4 & 0.484 & 0.698 & 0.408 & 0.34 \\
\hline & PK3 & 0.862 & 0.71 & 0.742 & 0.692 & & LK5 & 0.483 & 0.634 & 0.398 & 0.386 \\
\hline & PK4 & 0.622 & 0.483 & 0.533 & 0.569 & & LK7 & 0.687 & 0.838 & 0.621 & 0.629 \\
\hline & PK7 & 0.811 & 0.566 & 0.639 & 0.55 & & LK8 & 0.659 & 0.83 & 0.66 & 0.65 \\
\hline & PK8 & 0.863 & 0.699 & 0.679 & 0.606 & \multirow{10}{*}{$\mathrm{OCB}(\mathrm{Y})$} & $\mathrm{OCBl}$ & 0.487 & 0.457 & 0.621 & 0.704 \\
\hline & PK9 & 0.811 & 0.63 & 0.68 & 0.591 & & $O C B 2$ & 0.348 & 0.367 & 0.479 & 0.624 \\
\hline \multirow{8}{*}{$\begin{array}{l}\text { Organizational } \\
\text { Commitment } \\
\text { (Xmed) }\end{array}$} & KO1 & 0.789 & 0.723 & 0.875 & 0.719 & & $\mathrm{OCB} 3$ & 0.572 & 0.483 & 0.592 & 0.71 \\
\hline & $\mathrm{KO} 2$ & 0.716 & 0.66 & 0.849 & 0.703 & & OCB4 & 0.483 & 0.439 & 0.518 & 0.634 \\
\hline & $\mathrm{KO} 3$ & 0.644 & 0.652 & 0.803 & 0.751 & & OCB5 & 0.385 & 0.452 & 0.438 & 0.606 \\
\hline & $\mathrm{KO} 4$ & 0.701 & 0.57 & 0.854 & 0.731 & & OCB6 & 0.487 & 0.562 & 0.572 & 0.751 \\
\hline & KO5 & 0.472 & 0.441 & 0.635 & 0.534 & & $\mathrm{OCB} 7$ & 0.403 & 0.381 & 0.456 & 0.605 \\
\hline & KO6 & 0.692 & 0.626 & 0.815 & 0.636 & & OCB8 & 0.576 & 0.536 & 0.721 & 0.815 \\
\hline & $\mathrm{KO} 7$ & 0.564 & 0.477 & 0.778 & 0.667 & & OCB9 & 0.606 & 0.544 & 0.653 & 0.791 \\
\hline & KO8 & 0.577 & 0.464 & 0.724 & 0.594 & & $\mathrm{OCB} 10$ & 0.711 & 0.623 & 0.808 & 0.816 \\
\hline
\end{tabular}

Then reliability test based on composite reliability and cronbach's alpha with each condition above 0.70 then instrument will be considered as reliable.

Table 4. Reliability

\begin{tabular}{lcc}
\hline \multicolumn{1}{c}{ Variable } & Composite Reliability & Cronbach's Alpha \\
\hline Leadeship Behavior (X1) & 0.924 & 0.902 \\
\hline Work Environment (X2) & 0.883 & 0.837 \\
\hline Organizational Commitment (Xmed) & 0.932 & 0.915 \\
\hline OCB (Y) & 0.909 & 0.889 \\
\hline
\end{tabular}

\section{Inner Model Evaluation}

First step to examined these determination coefficients by looking at value of $\mathrm{R}$ Square, where Ghozali and Latan (2015) explain that value of R-Square 0.75; 0.50; 0.25 which is strong, moderate and weak model. 
Table 5. R-Square

\begin{tabular}{lc}
\hline \multicolumn{1}{c}{ Variable } & R-Square \\
\hline Organizational Commitment (Xmed) & 0.692 \\
\hline OCB (Y) & 0.722 \\
\hline
\end{tabular}

From these results it could be concluded that between leadership behavior and work environment had Moderately affect by organization commitment and OCB. Further step was conducted Goodness of Fit Index (GoF) test.

$$
\begin{aligned}
\text { GoF Index } & =\sqrt{ } \text { AVE } \times R^{2} \\
& =\sqrt{ }((0,636+0,605+0,632+0,504) / 4) \times((0,692+0,722) / 2) \\
& =\sqrt{ }(0,594 \times 0,707) \\
& =0,648
\end{aligned}
$$

Based on calculation, it could be said that GoF Index value was considered bigger than 0.36. And the last step was conduct hypothesis test, which earned table value of 1.97377 with significant level from significance $(\alpha)$ of 0.05 .

Table 6. Path Coefficients

\begin{tabular}{llll}
\hline \multicolumn{1}{c}{ Construct Correlation } & Original Sample & T Statistics & P Valves \\
\hline Direct & & & \\
\hline Leadership Behavior => OCB & 0.037 & 0.387 & 0.699 \\
\hline Leadership Behavior => Organizational Commitment & 0.632 & 8.542 & 0.000 \\
\hline Work Environment => OCB & 0.141 & 2.228 & 0.026 \\
\hline Work Environment => Organizational Commitment & 0.237 & 3.003 & 0.003 \\
\hline Organizational Commitment => OCB & 0.709 & 9.718 & 0.000 \\
\hline Indirect & & & \\
\hline Leadership Behavior => Organizational Commitment => & 0.448 & 5.937 & 0.000 \\
\hline Work Environment => Organizationa1 Commitment => OCB & 0.168 & 3.022 & 0.003 \\
\hline Total & & & \\
\hline Leadership Behavior => OCB & 0.486 & 5.777 & 0.000 \\
\hline Work Environment => OCB & 0.308 & 3.724 & 0.000 \\
\hline
\end{tabular}

Based on this research's results it was showed that direct influence from leadership behavior to OCB did not huge. These results were in line with prior research that conducted by Olcer (2014) and opposite to Dartey-Baah research (2019). However, when its mediated by organization commitment, then it became positive and significant influence towards OCB. Leadership behavior also had positive and significant influence over organization commitment and were in line with Ananda's research (2017), and organizational commitment had positive and significant impact towards OCB that were in line with Mahardika's research (2017). This becomes a hub between leadership behaviors which affect by organization commitment variable and would had an impact towards OCB. In this case, organization commitment acts as perfect mediator between leadership behavior to OCB.

1) According to this research it shown that there had positive and significant influence which occurs from work environment to OCB and were in line with Waspodo research [5], so it said if work environment gets better then OCB also get higher, besides this influence from work environment to OCB could be stronger if it was mediated by organization commitment. In this research shows that work environment had positive and significant influence over organization commitment and were line with Umamaheswari research [2] explained earlier that organization commitment had positive and significant impact 
towards OCB and organization commitment strengthens it. So it said that organization commitment acts as partial mediator between work environment and OCB.

\section{CONCLUSION AND SUGGESTION}

\section{Conclusion}

From these research results it could be concluded that direct influence from leadership behavior to OCB gives positive impact but not significant, by indirect impact from mediating organization commitment variable, it was Strengthen the leadership behavior influence towards OCB which now become positive and significant impact. So, it could be concluded that organization commitment perfectly mediated leadership behavior influence on OCB. And the direct influence of work environment on OCB gave smaller impact than the indirect one. So, it could be said that organization commitment had partially mediated the influence from work environment to OCB.

\section{REFERENCE}

A. A. Waspodo, Lindawati, and Sholikhah, "Pengaruh Kepuasan Kerja dan Lingkungan Kerja terhadap Organizational Citizenship Behavior Karyawan Perum DAMRI Kantor Pusat", JRMSI-Jurnal Riset Manajemen Sains Indonesia, vol. 10, no. 1, pp. 185-203, 2019.

C. Pingping and Y. J. Huang, "A Study of Association among Distributed Leadership, Organizational Commitment, and Organizational Citizenship Behavior of Private Colleges in China”, International Journal of Organizational Innovation (Online), vol. 12, no. 2, pp. 105-114, October 2019.

E. Pitaloka and I. P. Sofia, "The Effect of Work Environment, Job Satisfaction, Organization Commitment on OCB of Internal Auditors", International Journal of Business, Economics and Law, vol. 5, no. 2, pp. 10-18, December 2014.

F. Luthans, Organizational Behavior: An Evidence-Based Approach, New York, McGraw-Hill Education, 2011.

F. Olcer, M. S. Florescu, and M. Nastase, "The Effects of Transformational Leadership and Emotional Intelligence of Managers on Organizational Citizenship Behaviors of Employees", Revista de Management Comparat International, vol. 15, no. 4, pp. 385-401, October 2014.

G. A. Yukl, Leadership in Organizations, $8^{\text {th }}$ edition, New Jersey, Pearson Education, 2013.

I. Ghozali and H. Latan, Konsep, Teknik, Aplikasi Menggunakan Smart PLS 3.0 Untuk Penelitian Empiris, Semarang, BP Undip, 2015.

I. N. B. P. Mahardika and I. M. A. Wibawa, "Pengaruh Budaya Organisasi Kepuasan Kerja dan Komitmen Organisasional terhadap Organizational Citizenship Behavior pada Karyawan”, E-Jurnal Manajemen, vol. 8, no. 1, pp. 7340-7370, 2019.

K. Dartey-Baah, A. Anlesinya, and Y. Lamptey, "Leadership Behaviors and Organizational Citizenship Behavior: The Mediating Role of Job Involvement", International Journal of Business, vol. 24, no. 1, pp. 74-95, March 2019.

K. Kartono, Pemimpin dan Kepemimpinan, Jakarta, PT. Rajagrafindo Persada, 2011. 
Menteri Ketenagakerjaan, Peraturan Menteri Ketenagakerjaan Republik Indonesia nomor 5 tahun 2018 tentang Keselamatan dan Kesehatan Kerja Lingkungan Kerja, Jakarta, Kementerian Ketenagakerjaan, 2018

M. Shanker, "Organizational Citizenship Behavior and Organizational Commitment in Indian Workforce”, Journal of Psychosocial Research, vol. 11, no. 2, pp. 397-408, 2016.

Sedarmayanti, Tata Kerja dan Produktivitas Kerja. Bandung, CV Mandar Maju, 2015.

S. Ananda and H. Winata, "Upaya Meningkatkan Komitmen Organisasi melalui Perilaku Kepemimpinan", Jurnal Pendidikan Manajemen Perkantoran (JPManper), vol. 2, no. 1, pp. 78-86, January 2017.

S. J. Lo, "Pengaruh Kepemimpinan Organisasional dan Moderator Turbulensi Lingkungan terhadap Retensi Karyawan (Kasus pada Perusahaan-Perusahaan Publik di Jabodetabek)", Jurnal Manajemen \& Agribisnis, vol. 8, no. 1, pp. 41-49, March 2011.

S. P. Robbins and T Judge, Essentials of Organizational Behavior, $14^{\text {th }}$ edition, New Jersey, Pearson Education, 2018.

S. Syahriani and N. Nurwati, "Pengaruh Lingkungan Kerja terhadap Kepuasan Kerja dan Organizational Citizenship Behavior”, Jurnal Manajemen, Bisnis dan Organisasi (JUMBO), vol. I, no. 2, pp. 19-26, August 2017.

S. Umamaheswari and J. Krishnan, "Work Force Retention: Role of Work Environment, Organization Commitment, Supervisor Support and Training \& Development in Ceramic Sanitary Ware Industries in India", Journal of Industrial Engineering and Management (JIEM), vol. 9, no. 3, pp. 612-633, June 2016. 